\title{
Residents' Perceptions towards Educational Tourism Impacts: The Role of Gender Differences
}

\author{
Maryam Ahmadian ${ }^{1}$, Asnarulkhadi Abu Samah ${ }^{1}$, Sarjit S. Gill ${ }^{1}$, Mohammed Bashir Saidu ${ }^{1} \&$ Roozbeh Babolian \\ Hendijani $^{2}$ \\ ${ }^{1}$ Department of Social and Development Sciences, Faculty of Human Ecology, Universiti Putra Malaysia, \\ Selangor, Malaysia \\ ${ }^{2}$ School of Hospitality and Tourism Management, Faculty of Business, Binus International University, Jakarta, \\ Indonesia \\ Correspondence: Maryam Ahmadian, Asnarulkhadi Abu Samah, Department of Social and Development \\ Sciences, Faculty of Human Ecology, Universiti Putra Malaysia, 43400, UPM Serdang, Selangor, Malaysia. \\ E-mail: marydian50@gmail.com; asnarulhadi@gmail.com
}

Received: December 11, 2013 Accepted: January 2, 2014 Online Published: June 25, 2014

doi:10.5539/ass.v10n13p1 URL: http://dx.doi.org/10.5539/ass.v10n13p1

\begin{abstract}
Urban residents were surveyed to identify their perceptions, attitudes and practices about educational tourism in Malaysia. The purpose of this paper was also to assess if there were gender differences in host communities towards educational tourism impacts. Descriptive and inferential statistical analysis was performed; the results demonstrated that there was a significant difference in gender on educational tourism impacts $(p<.05)$. The findings suggest that further qualitative studies should be done in order to value social and cultural factors concerning host communities, gender differences and tourism industry in Malaysia. The study could contribute to educational tourism policy, community development and sustainability in future programs.
\end{abstract}

Keywords: educational tourism, host community, perception, gender

\section{Introduction}

Community development and tourism has been acknowledged in the context of the global economy. The tourism business has promoted the economic growth of both the community and the nation (Davis et al, 1988; Getz, 1986; Perdue et al., 1990). Educational tourism has also claimed as a principal means to boost social and economic capital, and empowerment for learners and host communities worldwide (Pittman, 2003). The tourism industry is Malaysia's third most important industry after the manufacturing and palm oil sector (Asari et al., 2011). Besides, Malaysia has attained a world ranking of 11th in terms of total international student population around the worlds. To sustain this situation, Ministry of Higher Education has set a goal of 200,000 international students in Malaysia by the year 2020 (MOHE, 2011).

Educational tourism is a program whereby potential learners move to a location as a group with the aim of engaging in learning practice directly related to the location (Bodger, 1998). Since it is defined through people's movement, educational tourism depends on some essential elements such as age, gender, income level, occupation, education status, and socio-economic condition of an area which have an effect on the implementation of educational tourism (Bhuiyan et al., 2010). Educational tourism has been used as a multi-dimensional capacity and it lies in the human capital structure. Current emphasis on educational tourism development in Malaysia may change the perceptions of the quality of life among residents.

Previous studies have been carried out to recognize the impacts of tourism development from the resident's perspective (Belisle \& Hoy, 1980; Liu \& Var, 1986; Ap, 1992; King et al., 1993; Jurowski et al., 1997; Lankford \& Howard, 1994; Lindberg \& Johnson, 1997). While several investigations have been conducted about the impacts of tourism and host perceptions towards tourism development, there has been little empirical research on educational tourism impacts on the local residents. Host communities' perception, attitude, practice and their socio-demographic factors can explain variation in educational tourism development. Previous research showed that examining variation among local subgroups ignores possible differences in men's and women's orientations (Mason \& Cheyne, 2000). 
Exclusive attention is not also given to the gender differentiation in Malaysian communities towards educational tourism development. Thus, the aim of the present paper is to make a contribution to the educational tourism research by investigating the gender differentiation in host communities' perception towards educational tourism impact. For the present research, 'educational tourism' refers to a learning and training program where the learner (e.g. international students) spends some time in learning institutions(e.g. public and privates universities) in Malaysia. The term of 'local resident'/ 'host community' or 'dweller' in this paper refers to the residents who reside near the educational institutes in the Klang Valley and Nilai districts. Most of public and private universities and colleges are located in these districts such as Universiti Malaya, Universiti Kebangsaan Malaysia, Universiti Putra Malaysia, Universiti Teknologi Malaysia, International Islamic University Malaysia, Lim Kok Wing University, Sun Way College and INTI College.

\section{Methods}

The data for this paper were obtained from a cross sectional study entitled "Impacts of Educational Tourism on the Residents of the Klang Valley, Malaysia". More details of this study are available somewhere else (Samah et al., 2012; Samah \& Ahmadian, 2013; Samah et al., 2013). In summary, this survey implemented a non-random sampling procedure at five districts in Selangor along with Kuala Lumpur (Federal Territory) and Nilai, Negeri Sembilan. Though 'the Klang Valley' will refer to all study areas in this research.

The development of the questionnaire was based on previous literature review. Most of the items for the instrument were adopted from previous literature which had demonstrated high reliability. A reliability test was conducted on the items used in this study and the reliability coefficients ranged from .70 to .82 as shown in Table 1. A total of 700 respondents were involved in this study. The analysis was carried out using SPSS version 20.0 (SPSS, Inc., Chicago, IL).

Table 1. Reliability Coefficients for Dimensions of Perceived Tourism Impacts

\begin{tabular}{lcc}
\hline & \multicolumn{2}{c}{$(\mathbf{n}=\mathbf{7 0 0})$} \\
\cline { 2 - 3 } Variables & No. Items & Alpha $(\boldsymbol{\alpha})$ \\
\hline Economic Impact & 8 & .82 \\
Socio-cultural Impact & 12 & .70 \\
Environmental Impact & 7 & .71 \\
Practice & 6 & .74 \\
Attitude & 5 & .76 \\
\hline
\end{tabular}

\section{Results}

\subsection{Demographics Characteristics}

Respondents were posed to respond to five Likert scale statements about the proposed dimensions of educational tourism impacts; their attitude and practice in their community (see Table 1). The mean age of the respondents was 33.46 years old, within the age range of $18-67$. Males accounted for $60.4 \%$ of the respondents and female accounted for $39.6 \%$ respondents. The largest number of respondents $(51.6 \%)$ reported middle school as their highest level of education.

The results also showed approximately $77.3 \%$ of the respondents were Malay and it followed by Chinese (12\%) and Indians (9.7\%). Majority of respondents were Muslim (78.7\%) and had an employment in the services industries (39.7\%). The average of salary was RM 3474.91 and it varied so widely among residents from high income (RM 24000.00) to low income and no income respondents such as housewives and students (RM 0.00) (Abu Samah et al., 2012).

Table 2 shows the demographic characteristics (categorical variables) of the female residents to compare with the male residents. The average age of the female residents was 29.35 and the mean age of male residents was 36.14 years. Most female and male residents stated middle school as their highest level of educational attainment. The mean income for the respondents was above RM 3000.

The majority of female residents were employed in marketing-related positions (44\%) whereas most of male residents had service industry jobs (49.4\%). The results also showed the majority of the female and male residents were Malay and Muslim. 
Table 2. Demographic characteristic of residents $(n=700)$

\begin{tabular}{lcc}
\hline Variables & Frequency & Percentage \\
\hline Gender & & \\
Male & 423 & 60.4 \\
Female & 277 & 39.6
\end{tabular}

\section{Education}

$\begin{array}{lcc}\text { Elementary school } & 35 & 5 \\ \text { Middle school } & 361 & 51.6 \\ \text { College } & 132 & 18.9 \\ \text { Bachelor degree } & 126 & 18 \\ \text { Graduate degree } & 46 & 6.6\end{array}$

\section{Race}

$\begin{array}{lcc}\text { Malay } & 541 & 77.3 \\ \text { Chinese } & 84 & 12 \\ \text { Indian } & 68 & 9.7 \\ \text { Others } & 7 & 1\end{array}$

\section{Religion}

$\begin{array}{lcc}\text { Muslim } & 551 & 78.7 \\ \text { Buddha } & 63 & 9 \\ \text { Christian } & 31 & 4.4 \\ \text { Hindu } & 53 & 7.6 \\ \text { Others } & 2 & 0.3\end{array}$

\section{Occupation}

\begin{tabular}{lcc} 
Administration & 27 & 3.9 \\
Clerical & 37 & 5.3 \\
Marketing & 244 & 34.9 \\
Not working & 26 & 3.7 \\
Operators & 11 & 1.6 \\
Professionals & 77 & 11 \\
Services Industries & 278 & 39.7 \\
\hline
\end{tabular}

\subsection{Results from Statistical $t$-Tests}

To confirm if gender had any influence on the perceptions and attitude of the residents along with their practices towards educational tourism development, t-tests were used for each dimension studied (see Table 4). Statistical differences in perceptions of educational tourism impacts and residents' practice excised between female and male dwellers in the Klang Valley, Malaysia. Statistical differences were found for female and male perceptions of environmental impacts of educational tourism and residents' practice in this study $(p<.05)$. Results of bivariate analysis showed that there was no significant difference in perceptions of economic and socio-cultural impacts of educational tourism between female and male residents $(p>.05)$. The mean attitude to educational tourism development in male respondents was slightly higher than female respondents' attitude mean, which was not significant $(p=.312)$. 
Table 3. Test of significance between female and male residents on demographic factors (Chi-square test)

\begin{tabular}{|c|c|c|c|c|c|c|}
\hline \multirow[t]{2}{*}{ Demographic Characteristics } & \multicolumn{2}{|c|}{ Male $(n=423)$} & \multicolumn{2}{|c|}{ Female $(n=277)$} & \multirow[b]{2}{*}{$\chi^{2}$} & \multirow[b]{2}{*}{ Sig. } \\
\hline & $\mathbf{N}$ & $\%$ & $\mathbf{N}$ & $\%$ & & \\
\hline Job & & & & & 49.402 & .000 \\
\hline Operators & 4 & 0.9 & 7 & 2.5 & & \\
\hline Marketing & 122 & 28.8 & 122 & 44 & & \\
\hline Administration & 16 & 3.8 & 11 & 4 & & \\
\hline Clerical & 13 & 3.1 & 24 & 8.7 & & \\
\hline Services Industries & 209 & 49.4 & 69 & 24.9 & & \\
\hline Professional & 44 & 10.4 & 33 & 11.9 & & \\
\hline Not working & 15 & 3.5 & 11 & 4 & & \\
\hline Education & & & & & 25.207 & .000 \\
\hline Elementary school & 27 & 6.4 & 8 & 2.9 & & \\
\hline Middle school & 241 & 57 & 120 & 43.3 & & \\
\hline College & 73 & 17.3 & 59 & 21.3 & & \\
\hline Bachelor degree & 64 & 15.1 & 62 & 22.4 & & \\
\hline Graduate degree & 18 & 4.3 & 28 & 10.1 & & \\
\hline Race & & & & & 1.013 & .798 \\
\hline Malay & 329 & 77.8 & 212 & 76.5 & & \\
\hline Chinese & 51 & 12.1 & 33 & 11.9 & & \\
\hline Indian & 40 & 9.5 & 28 & 10.1 & & \\
\hline Other & 3 & 0.7 & 4 & 1.4 & & \\
\hline Religion & & & & & 3.022 & .554 \\
\hline Islam & 332 & 78.5 & 219 & 79.1 & & \\
\hline Buddha & 38 & 9 & 25 & 9 & & \\
\hline Christian & 16 & 3.8 & 15 & 5.4 & & \\
\hline Hindu & 35 & 8.3 & 18 & 6.5 & & \\
\hline Other & 2 & 0.5 & 0 & 0 & & \\
\hline Age & & & & & & \\
\hline Income & & & & & & \\
\hline
\end{tabular}

Table 4. Test of significance between female and male residents on educational tourism impacts

\begin{tabular}{lccccc}
\hline & Male & Female & & & \\
\hline & Mean & Mean & df & t - value & Sig. (2-tailed) \\
\hline Dimensions & 3.37 & 3.36 & 698 & .211 & .833 \\
Economic Impacts & 3.41 & 3.27 & 598.376 & 2.971 & $.003^{*}$ \\
Environmental Impacts & 3.41 & 3.31 & 602.126 & 2.391 & $.017^{*}$ \\
Practices & 3.57 & 3.51 & 698 & 1.011 & .312 \\
Attitude & 3.56 & 3.50 & 698 & 1.862 & .063 \\
Socio-cultural Impacts & 3.37 & 3.36 & 698 & .211 & .833 \\
Dimensions & 3.41 & 3.27 & 598.376 & 2.971 & $.003^{*}$ \\
\hline
\end{tabular}

Note: $* P<.05$

\section{Discussion}

The findings were organized into five dimensions: economic impacts; environmental impacts; socio-cultural impacts; attitude; and practices. The results of the study indicated that there were differences in some selected dimensions of educational tourism impacts between the female and male residents studied.

Based on this study, the male residents were statistically different from the female residents in perceptions of environmental impacts of tourism and practices towards international students. The results revealed that 
contacting with international students for the male residents in the Klang Valley take important place and they accepted more positive environmental impact of education tourism than the female residents. The results also demonstrated that the majority of the male residents are involved in service industry positions which may directly influence their perceived environmental impact. In other words, small businesses and service industry positions may affect the male residents' interaction with international students in their community and neighborhood.

While tourism may provide employment for female and male residents, the male residents might perceive that educational tourism provides them positive opportunities for environmental impacts such as better healthcare services and convenient public transport. Similarly, previous study showed that males were more positive about proposed tourism development than females (Mason \& Cheyne, 2000). Other research has also uncovered that men and women benefit differently as a result of tourism development in their communities (Enloe, 2001; Henderson, 1989; Hong, 1985; Levy \& Lerch, 1991; Monk \& Alexander, 1986; Smaoui, 1979; Smith, 1989; Harvey et al, 1995).

The analysis also showed that there was a significant variation in job and education between the female and male respondents. As one of the measures to improve national tourism is educational tourism program (Hamzah, 2004). It is, therefore, important to take into account the socio-demographic variables among local communities in the development of tourism. Analysis on various demographic characteristics assists researchers and Malaysia tourism officials and policy makers in providing a better understanding of local residents' views and their practices towards educational tourism. Nevertheless, there is a need to make sure that all socio-demographic factors are included in discussions concerning educational tourism development in future study.

\section{Conclusion}

This paper has two purposes. The first is to document local residents' perceptions on educational tourism in the Klang Valley, Malaysia where most universities are located. The second purpose is to show the gender differences in residents' perceptions on educational tourism impacts. The finding shows significant differences in perceptions with regard to educational tourism impacts between female and male residents.

As shown in this study, it is possible to evaluate the influence of gender on the perception, attitude and practice to educational tourism development. This helps to improve a sustained tourism program by involving all potential stakeholders, particularly local communities in tourism planning. This participation and involvement can be facilitated by increasing community (residents) awareness and education on the importance of educational tourism in Malaysia.

Additional qualitative studies are needed to understand cultural factors affecting residents' behaviors and gender differences regarding interaction with international students to improve effective educational programs in Malaysia.

Understanding how educational tourism is perceived by gender groups is important for tourism planners and higher education officials as they help to build a strong economy. The results suggest that there is a need for better communication between local residents and tourism officials along with the Ministry of Education to consider the residents' experiences on international students. Above all, it is high time we appreciate gender-based differentiation in tourism development and community-based programs. This study presents practical information for both the Ministry of Tourism and Culture and the Ministry of Education on educational tourism to prepare policies in consultation with all stakeholders to scale up sustainable tourism development programs in Malaysia.

\section{Acknowledgments}

We would like to say our thanks to Universiti Putra Malaysia for providing us the grant for this study. This project was funded by the Research University Grant Scheme (Project No: 0604101015RU) under Universiti Putra Malaysia.

\section{References}

Ap, J. (1992). Residents' perceptions on tourism impacts. Annals of Tourism Research, 19(4), 665-690.

Asari, F. F. A. H., Idris, A. R., \& Daud, N. M. (2011). Modeling education tourism using gravity model in Malaysian public higher education institutions. Australian Journal of Basic and Applied Sciences, 5(5), 1257-1274.

Belisle, F. J., \& Hoy, D. R. (1980). The perceived impact of tourism by residents. Annals of Tourism Research, 7 , 83-101. 
Bhuiyan, M. A. H., Islam, R., Siwar, C., \& Ismail, S. M. (2010). Educational Tourism and Forest Conservation: Diversification for Child Education. Procedia-Social and Behavioral Sciences, 7, 19-23.

Bodger, D. (1998). Leisure, learning, and travel. Journal of Physical Education, Recreation \& Dance, 69(4), 28-31.

Davis, D., Allen, J., \& Consenza, R. M. (1988). Segmenting local residents by their attitudes, interested and opinions toward tourism. Journal of Travel Research, 27(2), 2-8.

Enloe, C. (2001). Bananas, beaches and bases: Making feminist sense of international politics. University of California Press.

Getz, D. (1986). Models in tourism planing toward integration of theory and practice. Tourism Management, 7 , 21-32.

Hamzah, A. (2004). Policy and planning of the tourism industry in Malaysia. The 6th ADRF general meeting, Bangkok, Thailand.

Harvey, M. J., Hunt, J., \& Harris, C. C. (1995). Gender and community tourism dependence level. Annals of Tourism Research, 22(2), 349-366.

Henderson, K. A., Bialeschki, M. D., Shaw, S. M., \& Freysinger, V. J. (1989). A leisure of one's own: A feminist perspective on women's leisure. Venture Publishing Inc.

Hong, E. (1985). See the Third World while it lasts. The social and environmental impact of tourism with special reference to Malaysia. Consumers' Association of Penang.

Jurowski, C., Uysal, M., \& Williams, D. R. (1997). A theoretical analysis of host community resident reactions to tourism. Journal of Travel Research, 36(2), 3-11.

King, B., Pizam, A., \& Milman, A. (1993). Social impacts of tourism: Host perceptions. Annals of Tourism Research, 20, 650-655.

Lankford, S. V., \& Howard, D. R. (1994). Developing a tourism impact attitude scale. Annals of Tourism Research, 21(1), 121-139.

Levy, D. E., \& Lerch, P. B. (1991). Tourism as a factor in development implications for gender and work in Barbados. Gender and Society, 67-85.

Lindberg, K., \& Johnson, R. L. (1997). Modeling resident attitudes toward tourism. Annals of Tourism Research, 24(2), 402-424.

Liu, J. C., \& Var, T. (1986). Residents attitudes toward tourism impacts In Hawaii. Annals of Tourism Research, $13,193-214$.

Mason, P., \& Cheyne, J. (2000). Residents' attitudes to proposed tourism development. Annals of Tourism Research. 27(2), 391- 411.

MOHE. (2011). Higher education indicators 2009 - 2010. Putrajaya. Research and Planning Division.

Monk, J., \& Alexander, C. S. (1986). Free port fallout: Gender, employment, and migration on Margarita Island. Annals of Tourism Research, 13(3), 393-413.

Perdue, R. R., Long, P. T., \& Allen, L. (1990). Resident support for tourism development. Annals of Tourism Research. 17(4), 586-599.

Pittman, J. (2003). Empowering individuals, schools, and communities. In G. Solomon, N. J. Allen, \& P. Resta (Eds.), Toward Digital Equity: Bridging the Divide in Education. Needham H eights, Mass.: Allyn \& Bacon.

Samah, A. A., \& Ahmadian, M. (2013). Educational Tourism in Malaysia: Implications for Community Development Practice. Asian Social Science, 9(11), 17-23.

Samah, A. A., Ahmadian, M., Gill, S. S., \& Hendijani, R. B. (2012). Factors Affecting Educational Tourism Development among Local Communities in the Klang Valley, Malaysia. Life Science Journal, 9(4), 3298-3303.

Samah, A. A., Ahmadian, M., Gill, S. S., \& Hendijani, R. B. (2013). Residents' Attitude towards Educational Tourism in Malaysia. Asian Social Science, 9(13), 14-18.

Smaoui, A., \& de Kadt, E. (1979). Tourism and employment in Tunisia. Tourism. Passport to development? Perspectives on the social and cultural effects of tourism in developing countries, 101-110. 
Smith, V. L. (1989). Eskimo tourism: Micro-models and marginal men. Hosts and guests. The anthropology of tourism (2nd ed., pp. 55-82).

\section{Copyrights}

Copyright for this article is retained by the author(s), with first publication rights granted to the journal.

This is an open-access article distributed under the terms and conditions of the Creative Commons Attribution license (http://creativecommons.org/licenses/by/3.0/). 